\title{
Cooperativity of Three Fragments: Protonated or Methylated Makaluvamine, Water Molecule and Glutamic Acid Molecule in Twelve Complexes and their Stabilities. A Study Performed at B3LYP/6-31+G(d,p) Level
}

By Soleymane Koné, Sékou Diomandé \& El-Hadji Sawaliho Bamba

Université Félix Houphouët-BOIGNY

Abstract- Makaluvamines are used by intercalation in the DNA for the treatment of cancer cells such as colon cancer, prostate cancer, breast cancer.... This work studies energetic and geometrical parameters of stability of the 3-body complexes formed by six Makaluvamines, first protonated and then methylated by interactions with a water molecule and a glutamic acid molecule (Glu. Ac), a protein residue of topoisomerase II. This study was carried out by the quantum chemistry method of density functional theory (DFT). Firstly, we determined the energy of each super-molecule, the energies of all units of two fragments and one fragment in the geometries of the complexes. We have also determined the energies of 2-body and 3-body interaction, cooperativity, relaxation and total interaction. The results of these calculations helped to appreciate the rigidity of each fragment between the isolated and complex states. They also allowed knowing the stability of each complex and the contribution of each interaction term to this stability.

Keywords: makaluvamines, complexes, fragment (body), energy of cooperativity, energy of interaction, hydrogen bond (HB), DFT.

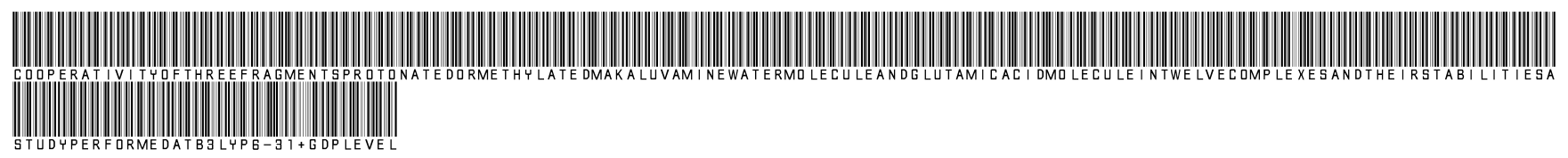

Strictly as per the compliance and regulations of:

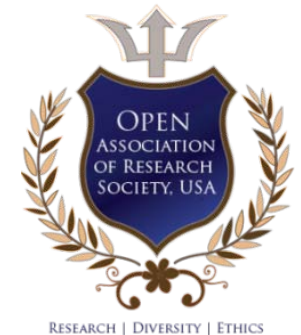

(c) 2020. Soleymane Koné, Sékou Diomandé \& El-Hadji Sawaliho Bamba. This is a research/review paper, distributed under the terms of the Creative Commons Attribution-Noncommercial 3.0 Unported License http://creativecommons.org/licenses/by$\mathrm{nc} / 3.0 /$ ), permitting all non commercial use, distribution, and reproduction in any medium, provided the original work is properly cited. 


\section{Cooperativity of Three Fragments: Protonated or Methylated Makaluvamine, Water Molecule and Glutamic Acid Molecule in Twelve Complexes and their Stabilities. A Study Performed at B3LYP/6-31+G(d,p) Level}

Soleymane Koné ${ }^{\alpha}$, Sékou Diomandé ${ }^{\sigma} \&$ El-Hadji Sawaliho Bamba ${ }^{\rho}$

Abstract-Makaluvamines are used by intercalation in the DNA for the treatment of cancer cells such as colon cancer, prostate cancer, breast cancer.... This work studies energetic and geometrical parameters of stability of the 3-body complexes formed by six Makaluvamines, first protonated and then methylated by interactions with a water molecule and a glutamic acid molecule (Glu. Ac), a protein residue of topoisomerase II. This study was carried out by the quantum chemistry method of density functional theory (DFT). Firstly, we determined the energy of each super-molecule, the energies of all units of two fragments and one fragment in the geometries of the complexes. We have also determined the energies of 2-body and 3-body interaction, cooperativity, relaxation and total interaction. The results of these calculations helped to appreciate the rigidity of each fragment between the isolated and complex states. They also allowed knowing the stability of each complex and the contribution of each interaction term to this stability. These calculations were used to consider the form (protonated or methylated) of these Makaluvamines suitable for docking. In a second step, we studied the interactions between the three bodies by using hydrogen bond $(\mathrm{HB})$ parameters. This analysis shows in which cases the hydrogen bonds formed are stronger. All theoretical calculations were performed at B3LYP/6-31+G(d,p). The BSSE correction was taken into account for the total interaction and cooperativity energies of the three fragments. Keywords: makaluvamines, complexes, fragment (body), energy of cooperativity, energy of interaction, hydrogen bond $(H B), D F T$.

\section{InTRODUCTION}

$\mathrm{n}$ the challenge of fighting cancer, one of the real causes of mortality worldwide [1,2], Makaluvamines represents a "green gold mine" for the scientific community. Indeed, the search for molecules that are "candidates for ideal drugs" against cancer conducted the study of extracts from marine plant organisms. They had found to contain compounds with unique pharmacological properties [3,4]. Makaluvamines are alkaloids extracted from marine algae with anticancer activities [5].

Author $\alpha \quad \sigma \quad \rho:$ Laboratoire de Chimie Organique et de Substances Naturelles de I'UFR SSMT, Université Félix Houphouët-BOIGNY, 22 BP 582 Abidbjan 22, Côte d'Ivoire. e-mail: konesol2003@yahoo.fr
In previous work, we have studied the hydrogen bond interactions of charged Makaluvamines with an $\mathrm{H}_{2} \mathrm{O}$ molecule and with a glutamic acid molecule (Glu Ac.) [6]. This work permitted to elucidate the geometric and energetic parameters of the interactions between two fragments, Makaluvamines charged with an $\mathrm{H}_{2} \mathrm{O}$ molecule or with the molecule of Glu Ac. using the density functional theory (B3LYP).

The current study, a continuation of the previous work, focuses on the formation of 3-body complexes between the charged (protonated or methylated) Makaluvamines and the two molecules of $\mathrm{H}_{2} \mathrm{O}$ and $\mathrm{Glu}$ Ac. Concerning super-molecule with more than two bodies, the cooperativity of the different fragments is very determining for its stability by interactions.

The goal of our study was to determine the energy contributions of each 2-body and 3-body interaction term to the stabilization of super-molecules. It will also allow us to discover in which form, protonated or methylated, the docking of Makaluvamines would give more stable complexes. Moreover, the calculations of the relaxation energies of the different bodies of each complex will allow us to discuss the degree of distortion of the geometry of each fragment between the isolated and complex states. The analysis of the geometric parameters of interactions in these three-body complexes was carried out by applying a hydrogen bond $(\mathrm{HB})$ criteria. All theoretical calculations in this work were done in the gas phase with the B3LYP functional associated with $6-31+G(d, p)$ basis set.

\section{Studied Makaluvamines And Methods of Calculation}

\section{a) Studied Makaluvamines}

This work has focused on twelve three-body complexes: protonated (or methylated) Makaluvamine + one molecule of $\mathrm{H}_{2} \mathrm{O}+$ one molecule of Glu Ac. Six Makaluvamines I, A, C, H, O, and $\mathrm{N}$ are involved in the formation of the complexes. The protonated $\left(\mathrm{XH}^{+}\right)$and methylated $\left(X^{\gamma}\right)$ 2D structures of these alkaloids were reported in figure 1. 
<smiles>NC1=CC2=NCCc3c[nH]c(c32)C1=O</smiles>

$\mathrm{IH}^{+}$<smiles></smiles>

$\mathrm{CH}^{+}$<smiles>O=C1C(=O)c2[nH]cc3c2C(=C1Br)NCC3</smiles><smiles>C[N+]1=C2C=C(N)C(=O)c3[nH]cc(c32)CC1</smiles>

$\mathbf{I}^{\mathrm{r}}$<smiles>Cc1[nH]c2c3c(c(C)[nH]c1-2)C(N)=CC3=O</smiles>

$\mathbf{C}^{r}$<smiles></smiles><smiles>Cn1cc2c3c1C(=O)C(N)=CC3=[NH+]CC2</smiles>

$\mathrm{AH}^{+}$<smiles>CC1=c2c(n(C)c3c(=O)c(N)c[nH]c23)=C1C</smiles>

$\mathrm{HH}^{+}$<smiles></smiles><smiles></smiles>

$A^{r}$<smiles></smiles>

$\mathbf{H}^{\text {r }}$<smiles>C[N+]1=C2C(Br)=C(N)C(=O)c3[nH]cc(c32)CC1</smiles>

Figure 1: 2D structures of studied Makaluvamines in 3-body complexes

\section{b) Methods of calculation}

Calculations were performed with the Gaussian 09 software [7]. The method used is the density functional theory (DFT) [8]. The hybrid functional B3LYP and others, when combined with an extended base of functions, give a good agreement between experimental and theoretical data of molecular properties [9]. Our choice has focused on the DFT/B3LYP method for all the theoretical calculations. An optimization calculation of the molecular geometry was performed on the twelve structures of figure 1 with one molecule of $\mathrm{H}_{2} \mathrm{O}$ and one molecule of Glu Ac. The 2-body and 3-body interaction energies were determined in these complexes. The "super-molecule" approach used here actually leads to an error on the variation of the total energy calculated during the formation of the complex. This error is due to the phenomenon of "Basis Set Superposition Error" or BSSE, which leads to an excessive energetic stabilization of the complex compared to the monomers. In a previous study on 2-body super-molecules of Makaluvamines [10], we have described the procedure for calculating the interaction, relaxation, and BSSE energies. For this work, calculations were performed at B3LYP/6-31+G(d,p) levels. i. Estimation of cooperative effects in 3-body complexes

The stability of a complex is always subject to nature (attractive or dispersive) of the various interactions between the fragments that constitute it. In other words, the interaction between fragments (or the energy of the interaction) is always disrupted by the adding of an additional fragment(s). In our approach, three fragments compose each complex. For example, the first designated A, represents protonated Makaluvamine or methylated Makaluvamine, and the last two fragments, designated $\mathrm{B}$ and $\mathrm{C}$, are a molecule of water and a molecule of glutamic acid, respectively. In the approach called "super-molecule" the interaction energy of the formed complexes can also be calculated according to equation 1 :

$$
\begin{gathered}
\Delta E=\Delta E_{r e l}(A)+\Delta E_{r e l}(B)+\Delta E_{r e l}(C)+\Delta E_{2 C}(A B)+ \\
\Delta E_{2 C}(B C)+\Delta E_{2 C}(A C)+\Delta E_{3 C}(A B C) \text { (éq. 1) }
\end{gathered}
$$

The relaxation energy, $\Delta E_{\text {rel }}$ reflects the distortion of geometry between the isolated and complexed states of a given fragment. The terms $\Delta E_{n c}$ are called $\mathrm{n}$-body energies. Two-body energies are in the majority of cases additive, while three-, four-, 
n-body energies are not additive. Indeed, two-body energy derived naturally from the interactions between two neighboring fragments. On the other hand, the interactions existing in the $\mathrm{ABC}$ complex (more than two bodies) cannot be expressed as a superposition of twobody interactions, first between $A$ and $B$, then between $\mathrm{B}$ and $\mathrm{C}$, and finally, between $\mathrm{A}$ and $\mathrm{C}$. It is the threebody term that reflects cooperative effects, the influence of a fragment $C$ on the interaction between $A$ and $B$ for example. Calculations of the two- and three-body terms are done in equations 2 and 3 respectively below:

$$
\begin{gathered}
\Delta E_{2 C}(A B)=E_{A B C}^{\alpha \cup \beta}(A B)-E_{A B C}^{\alpha}(A)-E_{A B C}^{\beta}(B) \\
\Delta E_{3 C}(A B C)=E_{A B C}^{\alpha \cup \beta \cup \gamma}(A B C)-\left\{E_{A B C}^{\alpha}(A)+E_{A B C}^{\beta}(B)+\right. \\
\left.E_{A B C}^{\gamma}(C)\right\}-\left\{E_{A B C}^{\alpha \cup \beta}(A B)+E_{A B C}^{\beta \cup \gamma}(B C)+E_{A B C}^{\alpha \cup \gamma}(A C)\right\}
\end{gathered}
$$

In the end, the corrected cooperativity energy of the BSSE in our complexes was calculated from the following equation 4 :

$$
\begin{aligned}
E_{\text {coop }}(B S S E)= & \Delta E_{3 C}(A B C)-\Delta E_{2 C}(A B)-\Delta E_{2 C}(B C)- \\
& \Delta E_{2 C}(A C)+B S S E
\end{aligned}
$$

ii. Geometric parameters of hydrogen bonds in complexes

The hydrogen $(\mathrm{HB})$ bond is an attractive interaction between a hydrogen atom of a molecule or molecular fragment $\mathrm{X}-\mathrm{H}$ in which $\mathrm{X}$ is more electronegative than $\mathrm{H}$, and an atom or group of atoms in the same molecule or a different molecule, in which there is evidence of bond formation [11].

The geometric analysis of the $\mathrm{HB}$ interactions of Makaluvamines with a molecule of $\mathrm{H}_{2} \mathrm{O}$ and GluAc were performed by the recommendations of Desiraju and Steiner [12], including the parameters defined in figure 2 .

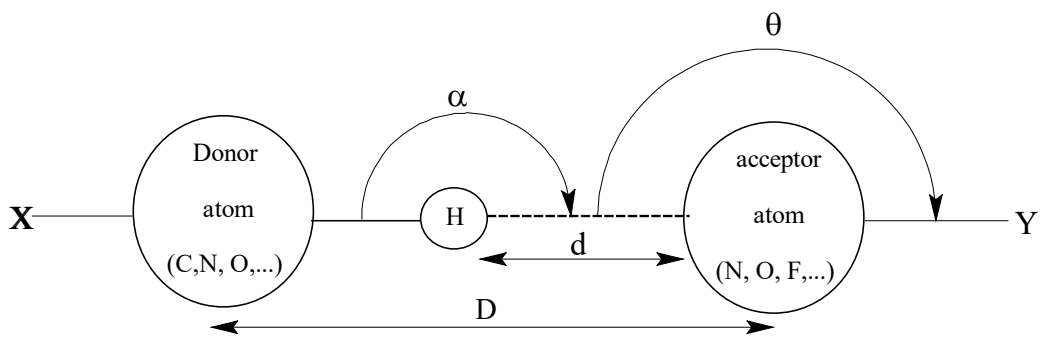

Figure 2: Geometric parameters $\mathrm{d}, \mathrm{D}, \propto$, and $\theta$ describing a hydrogen bond.

In this figure, $d$ is the length of the hydrogen bond expressed about the hydrogen atom (by putting $\mathrm{H}$ in the centre of the reference), $D$ is the distance between heavy atoms. The angles $\alpha$ and $\beta$ describe the linear and directional character of the hydrogen bond.
Figure 3 below shows the numbering of the different atoms of the Makaluvamines and the Ac Glu residue. This numbering permits a more precise description of the interactions by $\mathrm{HB}$ between the fragments in the studied super-molecules.
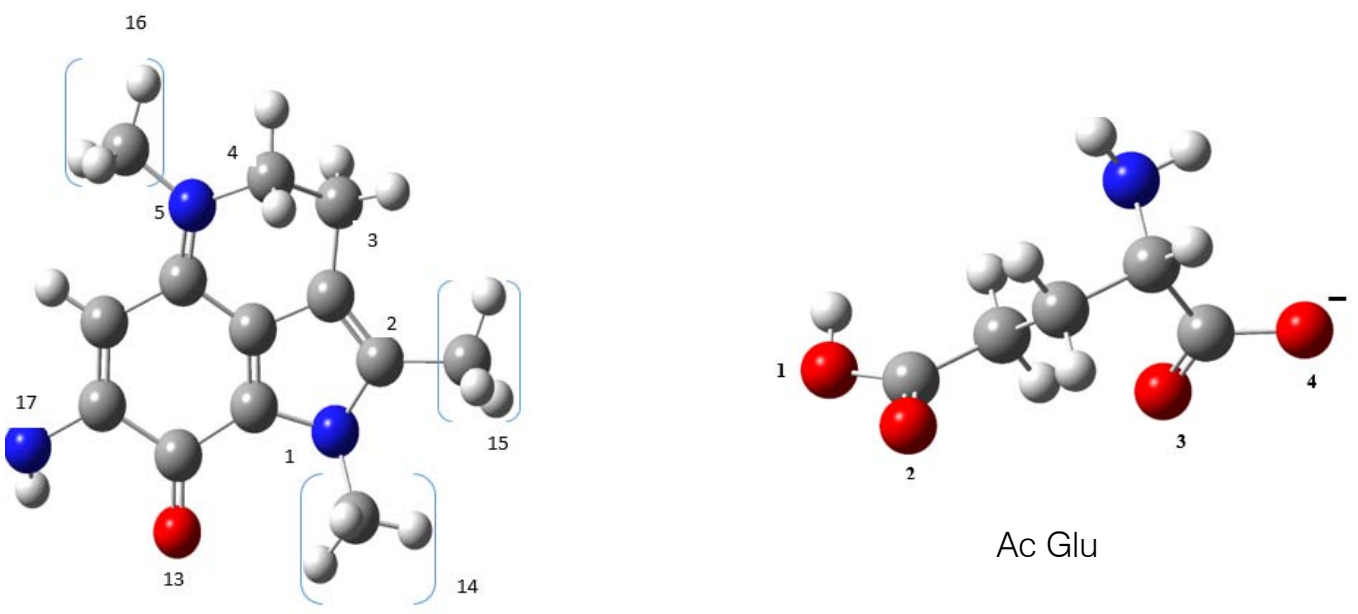

Ac Glu

$\mathrm{X}^{\gamma}$

Figure 3: Numbering used to describe the interactions (HB) between Makaluvamines and water and glutamic acid molecules. For protonated Makaluvamines $\mathrm{XH}^{+}, \mathrm{C}_{16} \mathrm{H}_{3}$ was replaced by $\mathrm{H}$. 


\section{ili. Results and Discussion}

a) Energy parameters of 3-body complexes

The geometries of 3-body super-molecules with protonated Makaluvamines $\left(\mathrm{XH}^{+}-\mathrm{H}_{2} \mathrm{O}-\mathrm{Ac} \mathrm{Glu}\right)$ optimized to the level of theory indicated are in Figure 4. The different energy parameters calculated for the six complexes of this figure were presented in table 1.
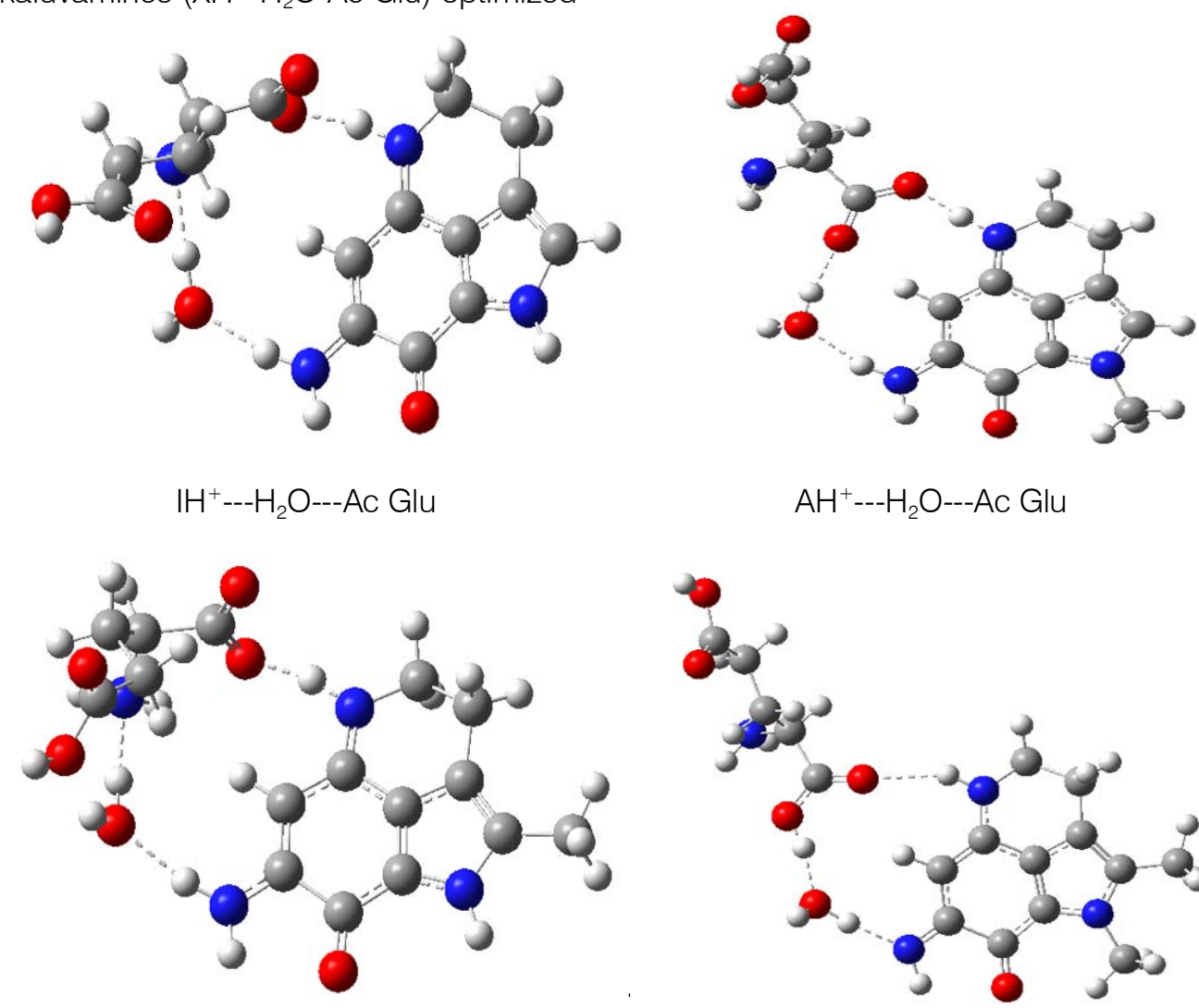

$\mathrm{AH}^{+}---\mathrm{H}_{2} \mathrm{O}---\mathrm{Ac} \mathrm{Glu}$

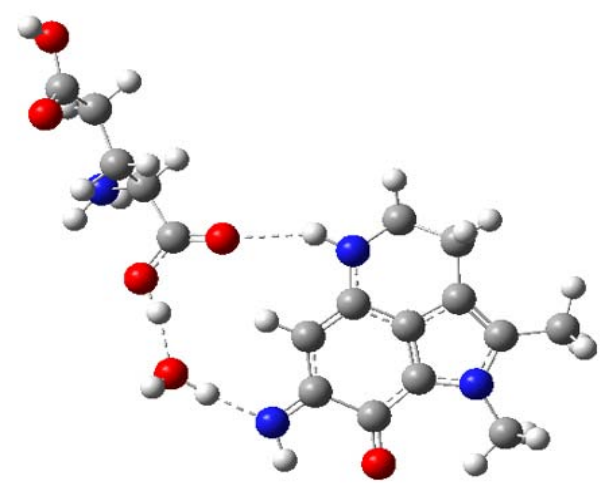

$\mathrm{CH}^{+}---\mathrm{H}_{2} \mathrm{O}---\mathrm{Ac} \mathrm{Glu}$

$\mathrm{HH}^{+}---\mathrm{H}_{2} \mathrm{O}---\mathrm{Ac}$ Glu

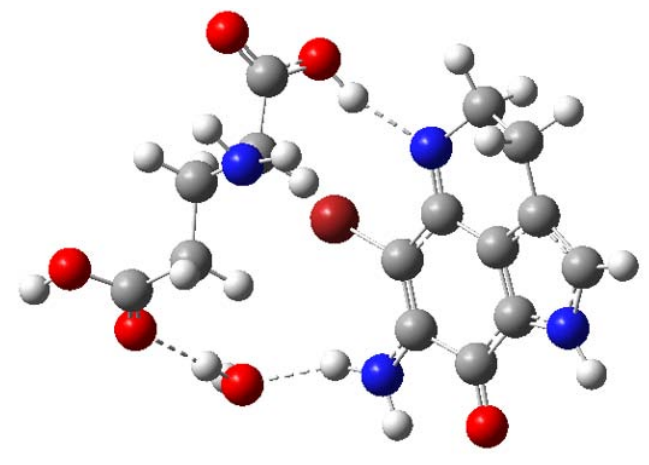

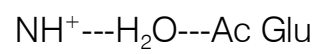

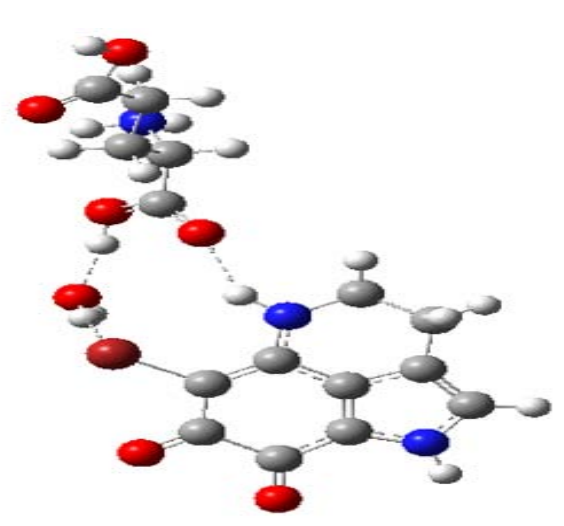

$\mathrm{OH}^{+}---\mathrm{H}_{2} \mathrm{O}---\mathrm{Ac}$ Glu

Figure 4: Optimized structures of 3-body complexes of a series of protonated Makaluvamines $\left(\mathrm{XH}^{+}\right)$with a molecule of $\mathrm{H}_{2} \mathrm{O}$ and a molecule of Ac Glu.

All of the structures of the complexes formed are in the form of three-membered ring structures: $\mathrm{XH}^{+}---\mathrm{H}_{2} \mathrm{O}--$ $-A c$ Glu---XH+. 
Table 1: Energies of the 3-body, 2-body, and 1-body molecular geometries in the geometry of the complex (CPL) $\mathrm{XH}^{+} \mathrm{YZ}$. Energies of the $\mathrm{XH}^{+}, \mathrm{Y}$, and $\mathrm{Z}$ bodies in their geometries (local), $\mathrm{XH}^{+}, \mathrm{Y}, \mathrm{Z}$ bodies relaxation and total relaxation, energies of the 2-body and 3-body interactions. BSSE corrected cooperativity energy. All these energies are in $\mathrm{kcal} / \mathrm{mol}$.

\begin{tabular}{|c|c|c|c|c|c|c|c|c|}
\hline Complexes & BSSE & $\mathrm{E}_{X H^{+}{ }^{+}(\mathrm{CPL})}$ & $\mathrm{E}_{\mathrm{YZ}(\mathrm{CPL})}$ & $\mathrm{E}_{\mathrm{XH}}{ }^{+} \mathrm{Z}(\mathrm{CPL})$ & $\mathrm{E}_{\mathrm{XH}}{ }^{+} \mathrm{YZ}(\mathrm{CPL})$ & $\mathrm{E}_{\mathrm{XH}}{ }^{+}(\mathrm{CPL})$ & $E_{Y(C P L)}$ & $\mathrm{E}_{\mathrm{Z}(\mathrm{CPL})}$ \\
\hline $\mathrm{IH}^{+} \ldots \mathrm{H}_{2} \mathrm{O} \ldots \mathrm{Ac} \mathrm{Glu}$ & 2.82 & -441058.87 & -393738.52 & -739031.13 & -787006.64 & -393082.02 & -47964.66 & -345850.34 \\
\hline $\mathrm{AH}^{+} \ldots \mathrm{H}_{2} \mathrm{O} \ldots \mathrm{Ac} \mathrm{Glu}$ & 2.11 & -465730.80 & -393829.78 & -763701.87 & -811679.08 & -417754.19 & -47964.66 & -345850.78 \\
\hline $\mathrm{CH}^{+} \ldots \mathrm{H}_{2} \mathrm{O} \ldots \mathrm{Ac} \mathrm{Glu}$ & 3.11 & -465737.85 & -393828.68 & -763706.67 & -811684.03 & -417761.18 & -47964.66 & -34585 \\
\hline $\mathrm{HH}^{+} \ldots \mathrm{H}_{2} \mathrm{O} \ldots \mathrm{Ac}$ Glu & 2.06 & -489985.16 & -394159.19 & -788 & -836 & $-442 C$ & -47964.66 & -346179.16 \\
\hline $\mathrm{NH}^{+} \ldots \mathrm{H}_{2} \mathrm{O} \ldots \mathrm{Ac}$ Glu & 7.15 & -2054096.37 & -394166.53 & -2352488.30 & -2400464.31 & -2006118.57 & -47964.66 & -346179.79 \\
\hline $\mathrm{OH}^{+} \ldots \mathrm{H}_{2} \mathrm{O} \ldots \mathrm{Ac} \mathrm{Glu}$ & 4.52 & -2066558.46 & -394159.05 & -2364953.91 & & & & \\
\hline
\end{tabular}

\begin{tabular}{|c|c|c|c|c|c|c|c|c|c|c|c|c|c|}
\hline Complexes & $\mathrm{E}_{\mathrm{XH}}{ }^{+}$(local) & $E_{Y(\text { local })}$ & $\mathrm{E}_{\mathrm{z} \text { (ocal) }}$ & $E_{R\left(X H^{+}\right)}$ & $E_{R M}$ & $E_{R(Z)}$ & $\Delta \mathrm{E}_{X \mathrm{X}^{+}{ }^{+} \mathrm{Y}}$ & $\Delta \mathrm{E}_{\mathrm{XH}}{ }^{+}-\mathrm{z}$ & $\Delta \mathrm{E}_{\mathrm{Y}-\mathrm{Z}}$ & $\Delta \mathrm{E}_{\mathrm{XH}}{ }^{+}{ }_{-\mathrm{Y}-\mathrm{Z}}$ & $\begin{array}{c}\mathrm{E}_{\text {coop }} \\
\text { (cor BSSE) }\end{array}$ & $E_{R}$ (tot) & $\Delta \mathrm{E}_{\text {int }}$ (tot) \\
\hline $\begin{array}{l}\mathrm{IH}^{+} \ldots \mathrm{H}_{2} \mathrm{O} \\
\ldots \text { Ac Glu }\end{array}$ & -393082.02 & -47980.02 & -345850.44 & 0.00 & 15.36 & 0.10 & -12.19 & -98.76 & -12.91 & 14.24 & 140.91 & 15.46 & -91.34 \\
\hline $\begin{array}{c}\mathrm{AH}^{+} \ldots \mathrm{H}_{2} \mathrm{O} \\
\ldots \mathrm{Ac} \text { Glu }\end{array}$ & -417754.19 & -47980.02 & -345850.44 & 0.00 & 15.36 & -0.34 & -11.96 & -96.90 & -14.34 & 13.75 & 139.06 & 15.03 & -92.32 \\
\hline $\begin{array}{c}\mathrm{CH}^{+} \ldots \mathrm{H}_{2} \mathrm{O} \\
\ldots \mathrm{Ac} \mathrm{Glu}\end{array}$ & -417761.18 & -47980.02 & -345850.44 & 0.00 & 15.36 & 0.36 & -12.01 & -95.41 & -13.95 & 13.25 & 137.72 & 15.73 & -89.28 \\
\hline $\begin{array}{c}\mathrm{HH}^{+} \ldots \mathrm{H}_{2} \mathrm{O} \\
\ldots \mathrm{Ac} \mathrm{Glu}\end{array}$ & -442432.72 & -47980.02 & -345850.44 & 421.52 & 15.36 & -328.72 & -9.31 & -178.18 & -15.37 & 5.97 & 210.88 & 108.17 & -86.66 \\
\hline $\begin{array}{c}\mathrm{NH}^{+} \ldots \mathrm{H}_{2} \mathrm{O} \\
\ldots \mathrm{Ac} \mathrm{Glu}\end{array}$ & -2006540.57 & -47980.02 & -345850.44 & 422.00 & 15.36 & -329.35 & -13.14 & -189.94 & -22.09 & 23.88 & 256.20 & 108.02 & -86.12 \\
\hline $\begin{array}{c}\mathrm{OH}^{+} \ldots \mathrm{H}_{2} \mathrm{O} \\
\ldots \text { Ac Glu }\end{array}$ & -2018961.71 & -47980.02 & -345850.44 & 381.00 & 15.36 & -328.72 & -13.10 & -194.04 & -15.24 & 17.67 & 244.57 & 67.65 & -132.53 \\
\hline
\end{tabular}

Body $\mathrm{XH}^{+}$: Protonated Makaluvamine; Body $\mathrm{Y}: \mathrm{H}_{2} \mathrm{O}$ and Body Z: Ac Glu

The total electronic energies $E_{X H^{+} Y Z(C P L)}$ of the three-body complexes in Table 1 range from -787006.64 $\mathrm{kcal}^{\mathrm{mol}}{ }^{-1}$ to $-2412929.23 \mathrm{kcal}^{\mathrm{mol}}{ }^{-1}$. These supermolecules are, therefore, very stable, particularly those formed by the protonated Makaluvamines $\mathrm{NH}^{+}$and $\mathrm{OH}^{+}$. These two complexes are, on average, 3 times more stable than those forming with the protonated Makaluvamines $\mathrm{IH}^{+}, \mathrm{AH}^{+}, \mathrm{CH}^{+}$, and $\mathrm{HH}^{+}$. The most stable of the structures was obtained with the protonated Makaluvamine $\mathrm{OH}^{+}$. The least stable of these super-molecules is that obtained with the reference Makaluvamine $\mathrm{IH}^{+}$(absence of substituent on the base skeleton). The introduction of substituents on this reference skeleton further stabilizes these complexes.

The energies of the 2-body fragments in the geometry of the complexes show that for a given structure, the two $\mathrm{XH}^{+}$---Ac Glu fragments are more stable. Their energy is much closer to that of the supermolecule. Secondly, we find the one of the two $\mathrm{XH}^{+}---\mathrm{H}_{2} \mathrm{O}$ fragments. The energies $E_{X H^{+} Z(C P L)}$ and $E_{X H^{+} Y(C P L)}$ respectively of the $\mathrm{XH}^{+}---A c$ Glu and $\mathrm{XH}^{+}---$ $\mathrm{H}_{2} \mathrm{O}$ fragments depend strongly on the geometry of the super-molecule. Of all the two-body fragments, $\mathrm{H}_{2} \mathrm{O}---$ Ac Glu has the highest energies $\left(E_{Y Z(C P L)}\right)$. They have the least stable geometries. Their energies seem to depend very little on the geometry of the supermolecule.

The analysis of the data of the 1-body fragments in the geometries of the complexes clearly shows that the values of the energies $E_{Y(C P L)}$ and $E_{Z(C P L)}$ respectively of the water and Ac Glu molecules are independent of this geometry. Only the $E_{X H^{+}(C P L)}$ energy of the protonated Makaluvamine is dependent on the geometry of the complex. For a given structure, the sum of the three energy values of the 1body fragments $\left(E_{X H^{+}(C P L)}+E_{Y(C P L)}+E_{Z(C P L)}\right)$ is always higher than that of the super-molecule. This shows that the total electronic energy of a complex is not a direct sum of the energies evaluated at the same level of constituent fragment theory in the geometry of the complex. The terms resulting from interactions must naturally were taken into account.

The relaxation energy $E_{R}$ shows that the geometry of the water molecule is subject to the same distortion in all the complexes studied. In the isolated state, this molecule is in a more stable conformation than in the complexed state. As for the fragments of the protonated Makaluvamines $\mathrm{IH}^{+}, \mathrm{AH}^{+}$, and $\mathrm{CH}^{+}$, the results indicate that their geometries do not show any deformation from their isolated states to the complexes they form. In the structures of these protonated Makaluvamines, the geometry of the glutamic acid molecule is very little modified compared to its isolated state. Finally, the water molecule is the fragment whose geometry was most modified during the formation of the three-body complexes from the protonated Makaluvamines $\mathrm{IH}^{+}, \mathrm{AH}^{+}$, and $\mathrm{CH}^{+}$. The interaction between the water molecule, the glutamic acid molecule, and each of the protonated Makaluvamines $\mathrm{HH}^{+}, \mathrm{NH}^{+}$, and $\mathrm{OH}^{+}$is associated with significant distortions of their geometries about their isolated states. In these complexes, the fragments are in less stable conformations. In these three super-molecules, 
the Ac Glu molecule faces the same relatively important structural distortion. This fragment adopts a lower energy conformation in the complexes than in the isolated state. In general, the Ac Glu fragment tends to take a molecular geometry of low energy in the complexes. The other two bodies $\left(\mathrm{XH}^{+}\right.$and $\left.\mathrm{H}_{2} \mathrm{O}\right)$, when their geometry is modified, are less stable than in the isolated state. No complex is formed without distortion of at least one fragment, as shown by $E_{R}(t o t) \neq 0$.

The 2-body interaction energies all have a stabilizing character. The terms $\Delta E_{X H^{+}-Y}$ and $\Delta E_{X H^{+}-Z}$, correspond respectively to the interactions $\mathrm{XH}^{+}---\mathrm{H}_{2} \mathrm{O}$ and $\mathrm{XH}^{+}---A c$ Glu. The values of $\Delta E_{X H^{+}-Y}$ are close to the interaction energies of the 2-body complexes formed by these two fragments [6]. This energy is the weakest contribution to the stabilization interaction in 3body complexes. The terms $\Delta E_{X H^{+}-Z}$ were compared to the energy of 2-body structures between protonated Makaluvamines and Ac Glu [6]. The interactions between these two fragments are much stronger in 3body complexes. The difference is apparent in the
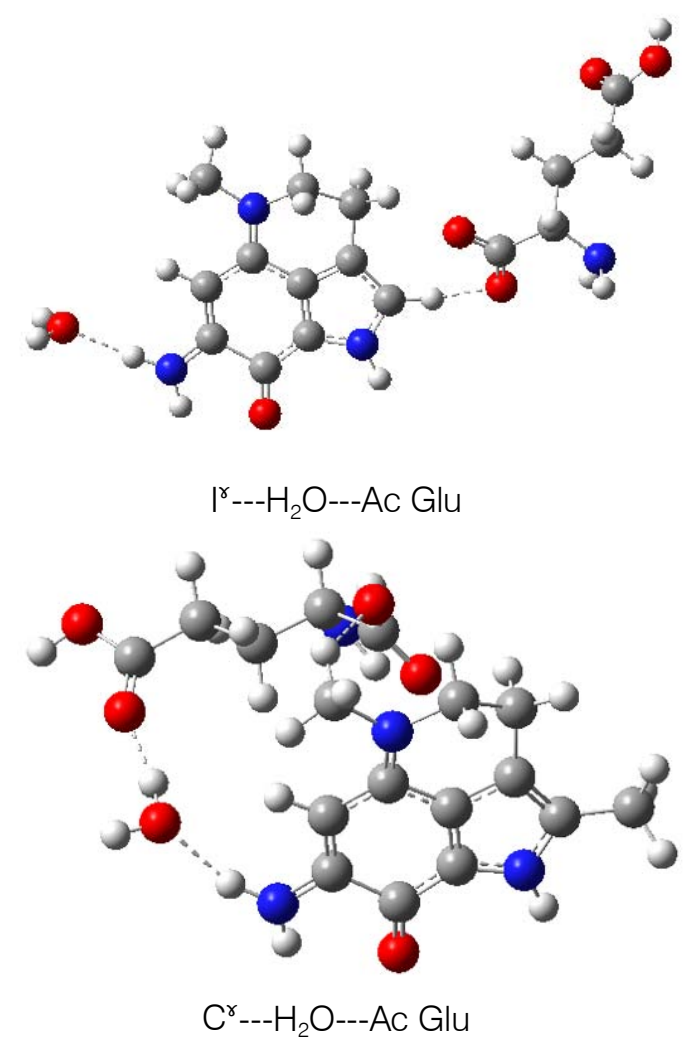

complexes formed by the protonated Makaluvamines $\mathrm{HH}^{+}, \mathrm{NH}^{+}$, and $\mathrm{OH}^{+}$. This 2-body interaction $\left(\mathrm{XH}^{+}---\mathrm{Ac}\right.$ $\mathrm{Glu}$ ) is the main contribution to the stabilization of supermolecules. The third 2-body term, $\Delta E_{Y-Z}$, corresponding to the interaction energy between the water molecule and the glutamic acid molecule is in the range of $-12.91 \mathrm{kcal}^{\mathrm{mol}}{ }^{-1}$ to $-22.1 \mathrm{kcal}^{\mathrm{mol}}{ }^{-1}$. The 3-body interaction $\Delta E_{X H^{+}-Y-Z}$ as expected, has a destabilizing character for complexes. This energy ranges from $+5.97 \mathrm{kcal}^{\mathrm{mol}}{ }^{-1}$ to $+23.88 \mathrm{kcal} . \mathrm{mol}^{-1}$. The sum of the 2-body and 3-body terms, the relaxation energies of the individual fragments, and the BSSE correction lead to the total interaction energy between the constituents in the super-molecule. This energy added to the terms of the three 1-body fragments in the geometry of the complex leads to a value that is sufficiently close to the total energy of each structure.

The optimized structures of the six complexes obtained with methylated Makaluvamines $\left(\mathrm{X}^{\gamma}-\mathrm{H}_{2} \mathrm{O}-\mathrm{Ac}\right.$ Glu) were showed in figure 5 . Their energy parameters were reported in table 2 .
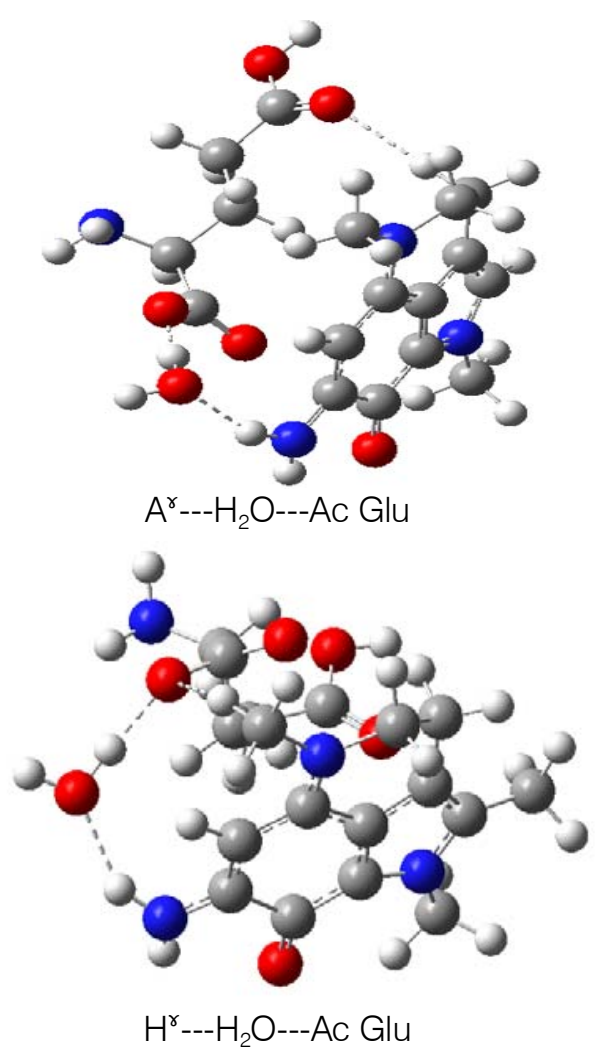

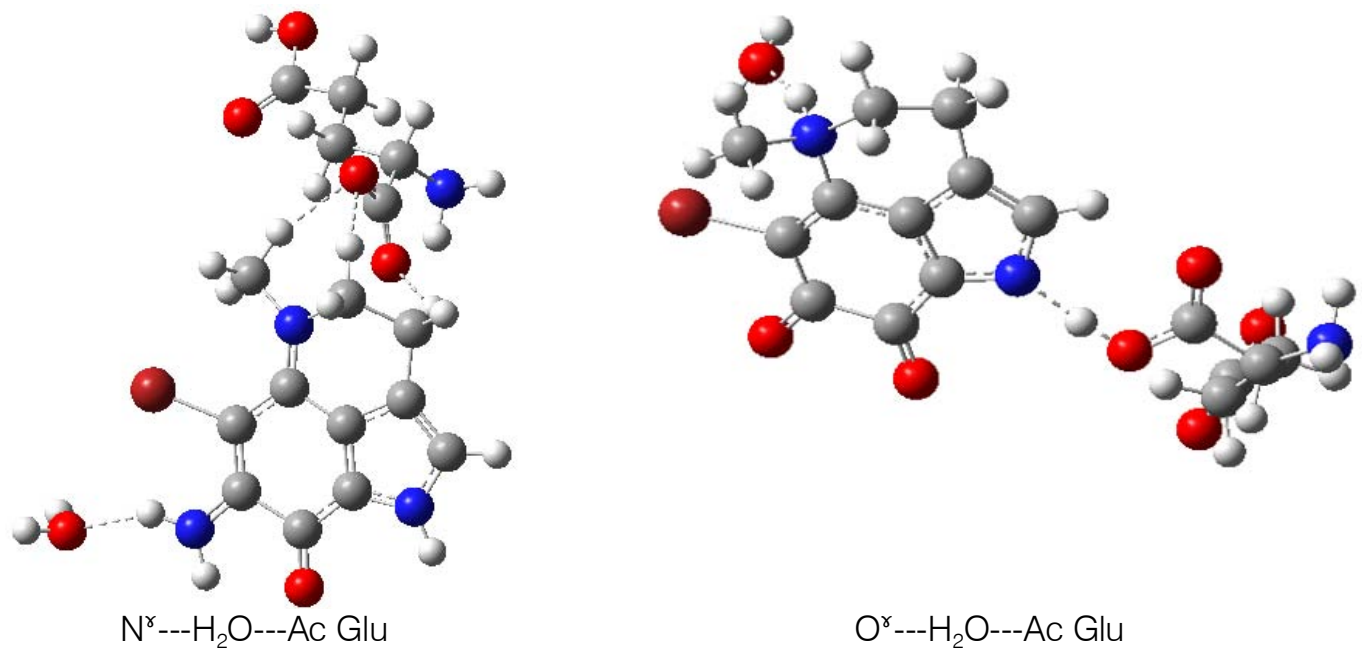

Figure 5: Optimized structures of 3-body complexes of a series of methylated Makaluvamines $\left(\mathrm{X}^{\curlyvee}\right)$ with a molecule of $\mathrm{H}_{2} \mathrm{O}$ and a molecule of Ac Glu.

The structures of the formed complexes are in the form of rings or linear chains.

Table 2: Energies of the 3-body, 2-body, and 1-body molecular geometries in the geometry of the complex (CPL) $X^{\gamma} Y Z$. Energies of the bodies $X^{\gamma}, Y$, and $Z$ in their geometries (local), $X^{\gamma}, Y, Z$ bodies relaxation and total relaxation, energies of 2-body and 3-body interactions. BSSE corrected cooperativity energy. All these energies are in $\mathrm{kcal} \cdot \mathrm{mol}^{-1}$.

\begin{tabular}{|c|c|c|c|c|c|c|c|c|}
\hline Complexes & BSSE & $E_{X Y(C P L)}^{\gamma}$ & $\mathrm{E}_{\mathrm{YZ}(\mathrm{CPL})}$ & $E_{X Z(C P L)}^{\gamma}$ & $E_{X}^{\gamma} Y Z(C P L)$ & $\mathrm{E}_{\mathrm{X}}^{\gamma}(\mathrm{CPL})$ & $\mathrm{E}_{\mathrm{Y}(\mathrm{CPL})}$ & $\mathrm{E}_{\mathrm{Z(CPL)}}$ \\
\hline $\mathrm{I}^{\gamma} \ldots \mathrm{H}_{2} \mathrm{O} \ldots \mathrm{Ac}$ Glu & 1.73 & -465728.80 & -393812.84 & -763675.89 & -811648.91 & -417752.24 & -47964.66 & -345850.34 \\
\hline $\mathrm{A}^{\gamma} \ldots \mathrm{H}_{2} \mathrm{O} \ldots \mathrm{Ac}$ Glu & 2.39 & -490400.50 & -393832.98 & -788353.77 & -836337.12 & -442424.19 & -47964.66 & -345850.34 \\
\hline $\mathrm{C}^{\gamma} \ldots \mathrm{H}_{2} \mathrm{O} \ldots \mathrm{Ac}$ Glu & 2.61 & -4904 & -3938 & -788 & -836 & -442 & -47 & \\
\hline $\mathrm{H}^{\gamma} \ldots \mathrm{H}_{2} \mathrm{O} \ldots \mathrm{Ac}$ Glu & 2.88 & -515078.75 & -393831.81 & -813025.74 & -861010.81 & -467102.63 & -47964.66 & -345849.04 \\
\hline $\mathrm{N}^{\gamma} \ldots \mathrm{H}_{2} \mathrm{O} \ldots \mathrm{Ac}$ Glu & 2.31 & -2079 & -393813.09 & -2377133.16 & -2425104.46 & -2031203.53 & -47964.66 & -345850.34 \\
\hline $\mathrm{O}^{\gamma} \ldots \mathrm{H}_{2} \mathrm{O} \ldots$ Ac Glu & 3.17 & -2091182.80 & -394159.15 & -2389571.63 & -2437550.24 & -2043200.92 & -47964.66 & -345850.29 \\
\hline
\end{tabular}

\begin{tabular}{|c|c|c|c|c|c|c|c|c|c|c|c|c|c|}
\hline Complexes & $E_{x}^{\gamma}$ (loca) & $\mathrm{E}_{\mathrm{Y} \text { (local) }}$ & $E_{Z \text { (ocal) }}$ & $E_{R}\left(x^{\gamma}\right)$ & $E_{R M}$ & $E_{R(Z)}$ & $\Delta E_{X-Y}^{\gamma}$ & $\Delta \mathrm{E}_{\mathrm{x} \cdot \mathrm{z}}^{\mathrm{\gamma}}$ & $\Delta \mathrm{E}_{\mathrm{Y}-\mathrm{Z}}$ & $\Delta \mathrm{E}_{\mathrm{X}-\mathrm{Y}-\mathrm{z}}^{\mathrm{\gamma}}$ & $\begin{array}{c}\mathrm{E}_{\text {coop }} \\
\text { (cor BSSE) }\end{array}$ & $E_{R}$ (tot) & $\Delta \mathrm{E}_{\mathrm{int}}$ (tot) \\
\hline $\begin{array}{l}I^{\gamma} . . \mathrm{H}_{2} \mathrm{O} . . \mathrm{Ac} \\
\text { Glu }\end{array}$ & -417752.24 & -47980.02 & -345850.44 & 0.00 & 15.36 & 0.10 & -11.90 & -73.31 & 2.16 & -345848.96 & -345764.17 & 15.46 & -345914.81 \\
\hline $\begin{array}{l}\mathrm{A}^{\gamma} . . \mathrm{H}_{2} \mathrm{O} . . \mathrm{Ac} \\
\text { Glu }\end{array}$ & -442424.19 & -47980.02 & -345850.44 & 0.00 & 15.36 & 0.10 & -11.65 & -79.24 & -17.97 & -345839.41 & -345728.16 & 15.46 & -345930.43 \\
\hline $\begin{array}{l}\mathrm{C}^{\gamma} . . \mathrm{H}_{2} \mathrm{O} . . \mathrm{Ac} \\
\text { Glu }\end{array}$ & -442431.32 & -47980.02 & -345850.44 & 0.00 & 15.36 & 0.10 & -11.71 & -80.75 & -13.24 & -345837.52 & -345729.21 & 15.46 & -345925.15 \\
\hline $\begin{array}{l}\mathrm{H}^{\gamma} . . \mathrm{H}_{2} \mathrm{O} . . \mathrm{Ac} \\
\text { Glu }\end{array}$ & -467102.63 & -47980.02 & -345850.44 & 0.00 & 15.36 & 1.40 & -11.47 & -74.07 & -18.12 & -345839.87 & -345733.33 & 16.77 & -345923.87 \\
\hline $\begin{array}{l}\mathrm{N}^{\gamma} . . \mathrm{H}_{2} \mathrm{O} . . \mathrm{Ac} \\
\text { Glu }\end{array}$ & -2031203.53 & -47980.02 & -345850.44 & 0.00 & 15.36 & 0.10 & -10.35 & -79.29 & -17.89 & -345828.76 & -345718.92 & 15.46 & -345918.50 \\
\hline $\begin{array}{l}\mathrm{O}^{\gamma} . . \mathrm{H}_{2} \mathrm{O} . . \mathrm{Ac} \\
\text { Glu }\end{array}$ & -2043627.25 & -47980.02 & -345850.44 & 426.34 & 15.36 & 0.15 & -17.22 & -520.43 & -344.20 & -345502.81 & -344617.80 & 441.85 & -345939.64 \\
\hline
\end{tabular}

Body X': Methylated Makaluvamine; Body Y: $\mathrm{H}_{2} \mathrm{O}$ and Body Z: Ac Glu

The values of the terms $E_{X} \gamma_{Y}$ z $(C P L)$ range from $-811648 \mathrm{kcal}^{\mathrm{mol}}{ }^{-1}$ to $-2437550.24 \mathrm{kcal}^{\mathrm{mol}}{ }^{-1}$. The energy of each $\mathrm{X}^{\gamma}-\mathrm{H}_{2} \mathrm{O}--\mathrm{Ac}$ Glu complex is at least 24621 to $24659 \mathrm{kcal}^{\mathrm{mol}}{ }^{-1}$ lower than that of the analog $\mathrm{XH}^{+}--\mathrm{H}_{2} \mathrm{O}--\mathrm{Ac} \mathrm{Glu}$. The 3-body super-molecules formed by the methylated Makaluvamines $I^{\gamma}, A^{\gamma}, C^{\gamma}, H^{\gamma}, N^{\gamma}$, and $\mathrm{O}^{\gamma}$ with $\mathrm{H}_{2} \mathrm{O}$ and Ac Glu are very stable compared to their analogs with the same protonated Makaluvamines. Similar to table 1, structures with the methylated Makaluvamines $\mathrm{N}^{\gamma}$ and $\mathrm{O}^{\gamma}$ are three times more low than those formed with $I^{\gamma}, A^{\gamma}, C^{\gamma}$, and $H^{\gamma}$. Analysis of the stability of two-fragment structures in the geometry of the complex shows that the $X^{\gamma}$---Ac Glu fragments are always the most stable. In second place in this classification are the two molecules $X^{\gamma}---\mathrm{H}_{2} \mathrm{O}$. The energies $\left.E_{X^{\gamma} Z(C P L)}\right)$ and $E_{X^{\gamma} Y(C P L)}$ respectively of the fragments $X^{\gamma}$---Ac Glu and $X^{\gamma}---\mathrm{H}_{2} \mathrm{O}$ depend strongly on the geometry of the super-molecule. The $\mathrm{H}_{2} \mathrm{O}---\mathrm{Ac}$ Glu fragments have the highest energies $\left(E_{Y Z(C P L)}\right)$ and are, therefore, the least stable. The values of the terms about two fragments depends very little on the geometry of the super-molecule.

The energies $E_{Y(C P L)}$ and $E_{Z(C P L)}$ respectively of the water and Ac Glu molecules (1-body fragments) in the geometries of the complexes clearly show that they do not depend on these geometries. Only the energy 
$E_{X^{\gamma}(C P L)}$ of the methylated Makaluvamine is always subject to the complex geometry. The sum of the terms of 1-body fragments $\left(E_{X^{\gamma}(C P L)}+E_{Y(C P L)}+E_{Z(C P L)}\right)$ in the complex geometry is not equal to the total energy of the complex. The relaxation energy $E_{R}\left(X^{\gamma}\right)$ shows that of all the methylated Makaluvamines studied, only the structure of $\mathrm{O}^{\gamma}$ was distorted between the isolated state and the complexed state. In this particular case, the Makaluvamine $\mathrm{O}^{r}$ is in a lower energy molecular geometry in the uncomplexed state. The geometry of the Ac Glu molecule was slightly distorted between the two states. This fragment is however, more stable in the isolated state. The geometry of the water molecule has the same distortion in all the complexes studied (tables 1 and 3). This fragment is always in a less stable conformation in the super-molecule.

Apart from the term $\Delta E_{Y-Z}$ corresponding to the interaction between the fragments $\mathrm{H}_{2} \mathrm{O}$ and $\mathrm{Ac}$ Glu in the complex $\left.\right|^{\gamma}-\mathrm{H}_{2} \mathrm{O}--\mathrm{Ac}$ Glu, the 2-body interaction energies all have a stabilizing character. The interaction energies $\Delta E_{X^{\gamma}-Y}$ between the fragments $X^{\gamma}$ (methylated Makaluvamines) and the $\mathrm{H} 2 \mathrm{O}$ molecule are always close to the interaction energies of the 2-body complexes formed by these fragments [6]. It is the lowest energy of the stabilization interaction in the complexes in Table 3. The interaction energies $\Delta E_{X^{\gamma}-Z}$ between the methylated Makaluvamines $X^{r}$ and Ac Glu are higher in 3-body complexes than in 2-body complexes [6]. Exceptionally, this interaction is four times stronger in the $\mathrm{O}^{\gamma}-\mathrm{H}_{2} \mathrm{O}-\mathrm{Ac}$ Glu complex than in the $I^{\gamma}$---Ac Glu complex. It is still the energy $\Delta E_{X^{\gamma}-Z}$ that constitutes the most important 2-body interaction for the stabilization of these 3-body complexes. The third 2-body term, $\Delta E_{Y-Z}$, indicates a strong interaction between the $\mathrm{H}_{2} \mathrm{O}$ molecule and the Ac Glu molecule in the complex $\mathrm{O}^{\gamma}--\mathrm{H}_{2} \mathrm{O}--\mathrm{Ac}$ Glu $\left(-344.20 \mathrm{kcal}^{\mathrm{mol}}{ }^{-1}\right)$. The energy of this interaction ranges from $-13.24 \mathrm{kcal}^{-\mathrm{mol}^{-1}}$ to $-17.89 \mathrm{kcal} \cdot \mathrm{mol}^{-1}$ for the complexes $\mathrm{A}^{\gamma}-\mathrm{H}_{2} \mathrm{O}--\mathrm{Ac} \mathrm{Glu}$, $\mathrm{C}^{\gamma}-\mathrm{H}_{2} \mathrm{O}-\mathrm{-Ac} \mathrm{Glu}, \mathrm{H}^{\gamma}-\mathrm{H}_{2} \mathrm{O}-\mathrm{-Ac}$ Glu and $\mathrm{N}^{\gamma}-\mathrm{H}_{2} \mathrm{O}-\mathrm{-Ac} \mathrm{Glu}$. The 3-body interaction $\Delta E_{X^{\gamma}-Y-Z}$, unexpectedly, has a stabilizing character in these six complexes. It ranges from $-355502.81 \mathrm{kcal} . \mathrm{mol}^{-1}$ to $-345848.96 \mathrm{kcal}^{\mathrm{mol}}{ }^{-1}$.
This energy reflects the strong global interaction $\Delta E_{\text {int }}$ (tot) between all the fragments of these complexes. This global interaction $\Delta E_{\text {int }}(t o t)$ is estimated to range between $-345914.81 \mathrm{kcal}^{\mathrm{mol}}{ }^{-1}$ and $345939.64 \mathrm{kcal} . \mathrm{mol}^{-1}$. The 3-body interaction $\Delta E_{X^{\gamma}-Y-Z}$ doesn't contribute to the calculation of total energy of the complex, although it is stabilizing. Indeed, the total energy of each complex $\left(E_{X^{\gamma} Y Z}(C P L)\right)$ was obtained with a good approximation by summing the energies of the 1-body fragments in the geometry of the complex $\left(E_{X} \gamma(C P L)+E_{Y}(C P L)+E_{Z}(C P L)\right)$ and the terms of 2body interaction energies $\left(\Delta E_{X^{\gamma}-Y}+\Delta E_{X^{\gamma}-Z}+\Delta E_{Y-Z}\right)$. Since all 2- and 3-body interactions are stabilizing in these super-molecules with an exceptionally important contribution of the 3-body terms, we can affirm that the three fragments $X^{\gamma}, \mathrm{H}_{2} \mathrm{O}$, and Ac Glu cooperate very well in these complexes. The high values of $\Delta E_{X^{\gamma}-Y-Z}$ confirm this result.

In the final analysis, we note that for the six Makaluvamines studied, the 3-body complexes of the methylated forms are at least $24600 \mathrm{kcal} . \mathrm{mol}^{-1}$ more stable than those obtained with the protonated forms.

For a given protonated or methylated form, Makaluvamines $\mathrm{O}$ and $\mathrm{N}$ lead to the most stable complexes, the complex with Makaluvamine $\mathrm{H}$ has a low energy than those obtained with Makaluvamines $A$ and $\mathrm{C}$ having close stabilities. Makaluvamine, I form the least stable complex. The total energy of interactions in these 3-fragment complexes is also at least $345800 \mathrm{kcal}^{\mathrm{mol}}{ }^{-1}$ lower with methylated Makaluvamines. There is also better cooperativity of these in these complexes. All these results would indicate that the structures of the methylated Makaluvamines are more favorable for forming complexes by docking compared to those of the protonated Makaluvamines.

\section{b) Geometrical parameters of interactions in 3-body complexes}

These geometrical interaction parameters analyzed according to the $\mathrm{H}$-bond approach are reported in Table 3 for the six structures in figure 4 and Table 4 for the complexes in figure 5.

Table 3: Geometrical parameters of HB determined at B3LYP/6-31+G(d,p) level in complexes of protonated Makaluvamines interacting with an $\mathrm{H}_{2} \mathrm{O}$ molecule and an Ac Glu molecule.

\begin{tabular}{llllll}
\hline Complexes & Interactions & $\boldsymbol{\alpha}\left(^{\circ}\right)$ & $\boldsymbol{\theta}\left(^{\circ}\right)$ & $\boldsymbol{d}(\AA)$ & $\boldsymbol{D}(\AA)$ \\
\hline $\mathrm{IH}^{+}-\mathrm{H}_{2} \mathrm{O}-\mathrm{Ac}$ Glu & $\mathrm{N}_{5} \mathrm{H} \ldots \mathrm{O}_{4} \mathrm{C}_{5} \mathrm{H}_{9} \mathrm{~N}$ & 163.25 & 105.59 & 1.55 & 2.60 \\
& $\mathrm{~N}_{17} \mathrm{H} \ldots \mathrm{OH}_{2}$ & 168.35 & 127.20 & 1.86 & 2.87 \\
& $\mathrm{OH}_{2} \ldots \mathrm{NH}_{2}(\mathrm{Ac}$ glu $)$ & 175.93 & 110.91 & 1.79 & 2.79 \\
$\mathrm{AH}^{+}-\mathrm{H}_{2} \mathrm{O}-\mathrm{Ac}$ Glu & $\mathrm{N}_{5} \mathrm{H} \ldots \mathrm{O}_{4} \mathrm{C}_{5} \mathrm{H}_{9} \mathrm{~N}$ & 175.71 & 126.71 & 1.52 & 2.61 \\
& $\mathrm{~N}_{17} \mathrm{H} \ldots \mathrm{OH}_{2}$ & 165.93 & 114.48 & 1.87 & 2.88 \\
& $\mathrm{OH}_{2} \ldots \mathrm{O}_{3} \mathrm{C}_{5} \mathrm{H}_{9} \mathrm{~N}$ & 170.67 & 175.49 & 1.75 & 2.72 \\
$\mathrm{CH}^{+}-\mathrm{H}_{2} \mathrm{O}-\mathrm{Ac} \mathrm{Glu}$ & $\mathrm{N}_{5} \mathrm{H} \ldots \mathrm{O}_{4} \mathrm{C}_{5} \mathrm{H}_{9} \mathrm{~N}$ & 164.81 & 115.24 & 1.50 & 2.57 \\
& $\mathrm{~N}_{17} \mathrm{H} \ldots \mathrm{OH}_{2}$ & 169.52 & 121.10 & 1.84 & 2.86 \\
& $\mathrm{OH}_{2} \ldots \mathrm{NH}_{2}(\mathrm{Ac} g l u)$ & 179.82 & 104.57 & 1.85 & 2.85 \\
$\mathrm{HH}^{+}-\mathrm{H}_{2} \mathrm{O}-\mathrm{Ac} \mathrm{Glu}$ & $\mathrm{N}_{5} \mathrm{H} \ldots \mathrm{O}_{3} \mathrm{C}_{5} \mathrm{H}_{9} \mathrm{~N}$ & 151.63 & 165.91 & 2.21 & 3.15 \\
\hline
\end{tabular}




\begin{tabular}{llllll}
\hline & $\mathrm{N}_{17} \mathrm{H} \ldots \mathrm{OH}_{2}$ & 173.97 & 106.71 & 1.01 & 2.73 \\
& $\mathrm{OH}_{2} \ldots \mathrm{O}_{3} \mathrm{C}_{5} \mathrm{H}_{9} \mathrm{~N}$ & 165.08 & 114.98 & 1.01 & 2.63 \\
$\mathrm{NH}^{+}-\mathrm{H}_{2} \mathrm{O}-\mathrm{Ac} \mathrm{Glu}$ & $\mathrm{N}_{5} \mathrm{H} \ldots \mathrm{O}_{4} \mathrm{C}_{5} \mathrm{H}_{9} \mathrm{~N}$ & 159.43 & 114.52 & 1.00 & 2.76 \\
& $\mathrm{~N}_{17} \mathrm{H}_{\ldots} \ldots \mathrm{OH}_{2}$ & 156.74 & 115.20 & 1.92 & 2.89 \\
& $\mathrm{OH}_{2} \ldots \mathrm{O}_{2} \mathrm{C}_{5} \mathrm{H}_{9} \mathrm{~N}$ & 177.44 & 136.09 & 1.87 & 2.84 \\
$\mathrm{OH}^{+}-\mathrm{H}_{2} \mathrm{O}-\mathrm{Ac} \mathrm{Glu}$ & $\mathrm{N}_{5} \mathrm{H}_{\ldots} \ldots \mathrm{O}_{3} \mathrm{C}_{5} \mathrm{H}_{9} \mathrm{~N}$ & 142.91 & 161.46 & 2.06 & 2.94 \\
& $\mathrm{OH}_{2} \ldots \mathrm{O}_{4} \mathrm{C}_{5} \mathrm{H}_{9} \mathrm{~N}$ & 171.04 & 112.05 & 1.00 & 2.67 \\
& $\mathrm{OH}_{2} \ldots \mathrm{BrOH}^{+}$ & 168.08 & 112.58 & 2.40 & 3.36 \\
\hline
\end{tabular}

Each fragment of these complexes establishes two interactions. As expected, $\mathrm{XH}^{+}$protonated Makaluvamines interact by preferred hydrogens (sites), namely $\mathrm{N}_{5} \mathrm{H}$ and $\mathrm{N}_{17} \mathrm{H}$ [6]. Ac Glu binds preferentially by its oxygen atoms $\mathrm{O}_{3}$ and $\mathrm{O}_{4}$ on $\mathrm{HN}_{5}$ to the protonated Makaluvamine. The water molecule is binding to the $\mathrm{XH}^{+}$ hydrogen $\mathrm{HN}_{17}$ through its oxygen. In the interaction between the Ac Glu and $\mathrm{H}_{2} \mathrm{O}$ fragments, water is frequently the donor and glutamic acid the acceptor. All the geometrical parameters of these interactions show values that are very favorable to the formation of $\mathrm{H}$ bonds. The linearity angle $\alpha$ ranges from $143^{\circ}$ to $180^{\circ}$. On average, this angle is $167^{\circ}$. The directionality parameter $\theta$, varies between $105^{\circ}$ and $176^{\circ}$, with an average of $125^{\circ}$. This angle is suitable for forming $\mathrm{H}$-bonds. Also, all the distances d between hydrogen and the acceptor atom are shorter than the sum of their Van Der Waals radii. The values are between $1.00 \AA$ and $2.06 \AA$. Thus, strong $\mathrm{H}$ bonds were established in these complexes between the different fragments.

Table 4: Geometrical parameters of $\mathrm{HB}$ determined at B3LYP/6-31+G(d,p) level in complexes of methylated Makaluvamines interacting with a molecule of $\mathrm{H}_{2} \mathrm{O}$ and a molecule of $\mathrm{Ac} \mathrm{Glu}$.

\begin{tabular}{|c|c|c|c|c|c|}
\hline Complexes & Interactions & $\alpha\left({ }^{\circ}\right)$ & $\theta\left({ }^{\circ}\right)$ & $d(\AA)$ & $D(\AA)$ \\
\hline \multirow{2}{*}{$\mathrm{I}^{\gamma}-\mathrm{H}_{2} \mathrm{O}-\mathrm{Ac}$ Glu } & $\overline{\mathrm{C}_{2}} \mathrm{H} \ldots \mathrm{O}_{4} \mathrm{C}_{5} \mathrm{H}_{9} \mathrm{~N}$ & 167.30 & 105.67 & 1.85 & 2.93 \\
\hline & $\mathrm{N}_{17} \mathrm{H} \ldots \mathrm{OH}_{2}$ & 175.58 & 122.60 & 1.94 & 2.95 \\
\hline \multirow[t]{3}{*}{$\mathrm{A}^{\gamma}-\mathrm{H}_{2} \mathrm{O}-\mathrm{Ac} \mathrm{Glu}$} & $\mathrm{OH}_{2} \ldots \mathrm{O}_{4} \mathrm{C}_{5} \mathrm{H}_{9} \mathrm{~N}$ & 176.94 & 130.34 & 1.59 & 2.60 \\
\hline & $\mathrm{C}_{3} \mathrm{H} \ldots \mathrm{O}_{2} \mathrm{C}_{5} \mathrm{H}_{9} \mathrm{~N}$ & 177.21 & 141.45 & 2.41 & 3.51 \\
\hline & $\mathrm{N}_{17} \mathrm{H} \ldots \mathrm{OH}_{2}$ & 150.24 & 98.59 & 1.80 & 2.79 \\
\hline \multirow[t]{3}{*}{$\mathrm{C}^{\gamma}-\mathrm{H}_{2} \mathrm{O}-\mathrm{Ac}$ Glu } & $\mathrm{C}_{16} \mathrm{H} \ldots \mathrm{O}_{4} \mathrm{C}_{5} \mathrm{H}_{9} \mathrm{~N}$ & 130.33 & 125.47 & 2.20 & 3.03 \\
\hline & $\mathrm{N}_{17} \mathrm{H} \ldots \mathrm{OH}_{2}$ & 160.97 & 119.40 & 1.89 & 2.88 \\
\hline & $\mathrm{OH}_{2} \ldots \mathrm{O}_{2} \mathrm{C}_{5} \mathrm{H}_{9} \mathrm{~N}$ & 169.59 & 151.62 & 1.83 & 2.80 \\
\hline \multirow[t]{3}{*}{$\mathrm{H}^{\gamma}-\mathrm{H}_{2} \mathrm{O}-\mathrm{Ac} \mathrm{Glu}$} & $\mathrm{C}_{16} \mathrm{H} \ldots \mathrm{O}_{4} \mathrm{C}_{5} \mathrm{H}_{9} \mathrm{~N}$ & 151.22 & 97.54 & 2.35 & 3.35 \\
\hline & $\mathrm{N}_{17} \mathrm{H} \ldots \mathrm{OH}_{2}$ & 146.04 & 117.86 & 1.95 & 2.86 \\
\hline & $\mathrm{H}_{2} \mathrm{O} \ldots \mathrm{O}_{3} \mathrm{C}_{5} \mathrm{H}_{9} \mathrm{~N}$ & 173.42 & 138.75 & 1.67 & 2.67 \\
\hline \multirow[t]{4}{*}{$\mathrm{N}^{\gamma}-\mathrm{H}_{2} \mathrm{O}-\mathrm{Ac}$ Glu } & $\mathrm{C}_{16} \mathrm{H} \ldots \mathrm{O}_{4} \mathrm{C}_{5} \mathrm{H}_{9} \mathrm{~N}$ & 160.05 & 98.34 & 2.05 & 3.10 \\
\hline & $\mathrm{N}_{17} \mathrm{H}_{\ldots} \ldots \mathrm{OH}_{2}$ & 149.95 & 123.79 & 2.00 & 2.92 \\
\hline & $\mathrm{C}_{3} \mathrm{H} \ldots \mathrm{O}_{3} \mathrm{C}_{5} \mathrm{H}_{9} \mathrm{~N}$ & 135.33 & 113.33 & 2.22 & 3.10 \\
\hline & $\mathrm{C}_{4} \mathrm{H} \ldots \mathrm{O}_{4} \mathrm{C}_{5} \mathrm{H}_{9} \mathrm{~N}$ & 146.47 & 107.13 & 2.18 & 3.15 \\
\hline \multirow[t]{2}{*}{$\mathrm{O}^{\gamma}-\mathrm{H}_{2} \mathrm{O}-\mathrm{Ac} \mathrm{Glu}$} & $\mathrm{N}_{1} \mathrm{H} \ldots \mathrm{O}_{4} \mathrm{C}_{5} \mathrm{H}_{9} \mathrm{~N}$ & 173.80 & 115.45 & 1.07 & 2.58 \\
\hline & $\mathrm{OH}_{2} \ldots \mathrm{N}_{5} \mathrm{H}$ & 159.11 & 135.08 & 1.62 & 2.64 \\
\hline
\end{tabular}

All interactions established to form these complexes were performed on privileged electrophilic (hydrogen) sites identified in the structures of the methylated Makaluvamines $X^{\gamma}[6]$.

The angular parameters satisfy the conditions for the formation of $\mathrm{H}$-bonds. Indeed, the angle of linearity $\alpha$ is wide open, on average $159^{\circ}$, indicating an appropriate alignment of the donor, hydrogen and acceptor atoms. Also, it was noted that the directionality angle $\theta$ defined between the one next to the acceptor and the hydrogen involved in the interaction is well above its lower limit, which is $90^{\circ}$. The spacing of the donor and acceptor atoms, $\mathrm{D}$, is between $2.58 \AA$ and $3.51 \AA$. It is, therefore, suitable for the formation of $\mathrm{H}$ bonds. The distances $d$ between hydrogen-acceptor in the $\mathrm{X}^{\gamma}$--- $\mathrm{H}_{2} \mathrm{O}---\mathrm{Ac}$ Glu complexes shown in table 4 range $1.07 \AA$ to $2.41 \AA$. Compared to those established in the $\mathrm{XH}^{+}---\mathrm{H}_{2} \mathrm{O}---\mathrm{Ac}$ Glu complexes in Table 2, they are longer. It can, therefore, was said that the $\mathrm{H}$ bonds in the $X^{\gamma}---\mathrm{H}_{2} \mathrm{O}---\mathrm{Ac}$ Glu structures are generally weaker than those in the $\mathrm{XH}^{+}---\mathrm{H}_{2} \mathrm{O}---\mathrm{Ac}$ Glu complexes. In contrary to 2-body super-molecules, in 3-body complexes, multicentric interactions are rarely observed. Only one case was observed, the $\mathrm{N}^{\gamma}---\mathrm{H}_{2} \mathrm{O}---\mathrm{Ac}$ Glu complex.

\section{Conclusion}

This study revealed that the complexes between the methylated Makaluvamines and the two fragments $\mathrm{H}_{2} \mathrm{O}$ and $\mathrm{Ac}$ Glu are very clearly more stable, by at least $24800 \mathrm{kj}^{\mathrm{mol}}{ }^{-1}$ than those formed between these two fragments and the protonated Makaluvamines. Two Makaluvamines $\mathrm{N}$ and $\mathrm{O}$ are distinguished for the stronger stability of their complexes. Their energies are at least three times lower than those of each of the super-molecules with Makaluvamines I, A, C, and $\mathrm{H}$. The study of cooperativity confirms as expected that all 2-body interactions in the twelve complexes contribute 
to stabilizing them. However, it has shown that the interaction between the three bodies is destabilizing during complex formation with protonated and stabilizing Makaluvamines when methylated Makaluvamines were used. In complexes with methylated Makaluvamines, there is better cooperativity of the three fragments. The total interaction energy in these complexes is at least $345800 \mathrm{kcal}^{\mathrm{mol}}{ }^{-1}$ lower than in complexes with protonated Makaluvamines. No super-molecule is formed without distortion of at least one fragment, as shown by $E_{R}(t o t) \neq 0$. In these complexes, the $\mathrm{H}$-bonds between the methylated Makaluvamines, water, and glutamic acid are more long than those in the structures of protonated Makaluvamines, water, and glutamic acid.

\section{Bibliographic References}

1. IARC, (2011). Cancer Incidence and Mortality Worlwide; International Agency for Research on Cancer: Lyon, France.

2. WHO, (2011). Global Status Report on Noncommunicable Diseases 2010; WT 500; WHO: Geneva, Switzerland.

3. Blunt J. W., Copp B. R., Munro M. H., Northcote P. T., Prinsep M. R. (2005) Marine natural products. Nat Prod Rep 22: 15-61.

4. Wang W., Rayburn E. R., Velu S. E., Nadkarni D. H., Murugesan S., and al. (2009). In vitro and in vivo anticancer activity of novel synthetic makaluvamine analogues. Clin Cancer Res 15(10): 3511-8.

5. Sipkema D., Franssen M. C., Osinga R., Tramper J. and Wijffels R. H. (2005). Marine sponges as pharmacy Mar. Biotechnol.7 142.

6. Diomandé S., Bédé A. L., Koné S., Bamba E. S. (2019). Study of molecular interactions by hydrogen bond of charged forms of makaluvamines and complex stability with $\mathrm{H}_{2} \mathrm{O}$ and glutamic acid (Glu Ac) by the theory of the functional of density (B3LYP). Journal of Molecular Modeling. Nov; 25(12): 344. DOI: 10.1007/s00894-019-4231-0.

7. Gaussian 09,(2009) Revision A.02, M. J. Frisch, G. W. Trucks, H. B. Schlegel, G. E. Scuseria, M. A. Robb, J. R. Cheeseman, G. Scalmani, V. Barone, B. Mennucci, G. A. Petersson, H. Nakatsuji, M. Caricato, X. Li, H. P. Hratchian, A. F. Izmaylov, J. Bloino, G. Zheng, J. L. Sonnenberg, M. Hada, M. Ehara, K. Toyota, R. Fukuda, J. Hasegawa, M. Ishida, T. Nakajima, Y. Honda, O. Kitao, H. Nakai, T. Vreven, J. A. Montgomery, Jr., J. E. Peralta, F. Ogliaro, M. Bearpark, J. J. Heyd, E. Brothers, K. N. Kudin, V. N. Staroverov, R. Kobayashi, J. Normand, K. Raghavachari, A. Rendell, J. C. Burant, S. S. lyengar, J. Tomasi, M. Cossi, N. Rega, J. M. Millam, M. Klene, J. E. Knox, J. B. Cross, V. Bakken, C. Adamo, J. Jaramillo, R. Gomperts, R. E. Stratmann, O. Yazyev, A. J. Austin, R. Cammi, C. Pomelli, J. W.
Ochterski, R. L. Martin, K. Morokuma, V. G. Zakrzewski, G. A. Voth, P. Salvador, J. J. Dannenberg, S. Dapprich, A. D. Daniels, O. Farkas, J. B. Foresman, J. V. Ortiz, J. Cioslowski, and D. J. Fox, Gaussian, Inc., Wallingford CT.

8. Hohenberg, P. Kohn, W. (1964). Inhomogeneous electron gas. Phys. Rev. 136, B864.

9. Koch, W., Holthausen, (1999) M.C.A in Chemist's Guide to Density Fonctional Theory $2^{\text {nd }}$ Ed, Wiley$\mathrm{VCH}$. Weinheim.

10. Elangannan A., Gautam R. D., Roger A. K., Joanna S., Steve S., IbonA.,....David J. N., (2011).Definition of the hydrogen bond (IUPAC Recommendations 2011), Pure Appl. Chem., Vol. 83, No. 8, pp. 1637-1641.

11. Desiraju, G., Steiner, T. (1999). The Weak Hydrogen Bond: Applications to Structural Chemistry and Biology, International Union of Crystallography Monographs on Crystallography. 